International Journal of Mechanical Engineering and Technology (IJMET)

Volume 12, Issue 4, April 2021, pp. 36-44. Article ID: IJMET_12_04_003

Available online at https://iaeme.com/Home/issue/IJMET?Volume $=12 \&$ Issue $=4$

ISSN Print: 0976-6340 and ISSN Online: 0976-6359

DOI: https://doi.org/10.34218/IJMET.12.4.2021.003

C IAEME Publication

Scopus Indexed

\title{
SIMULATION TESTS OF STATIC TENSILE TESTING OF THE AW 5083 ALLOY
}

\author{
Daria Zuk* \\ Uniwersytet Morski w Gdyni, Wydział Mechaniczny, \\ Ul.Morska 81-87, 81-225 Gdynia, Poland \\ ORCID :0000-0002-0810-0626 \\ Grzegorz Hajdukiewicz \\ Uniwersytet Morski w Gdyni, Wydział Mechaniczny, \\ Ul.Morska 81-87, 81-225 Gdynia, Poland \\ ORCID: 0000-0002-6068-3312 \\ Norbert Abramczyk \\ Uniwersytet Morski w Gdyni, Wydział Mechaniczny, \\ Ul.Morska 81-87, 81-225 Gdynia, Poland \\ *Corresponding Author
}

\begin{abstract}
The article attempts to model a static tensile test of a sample made of aluminum alloy $A W$ 5083. For this purpose, mechanical tests were carried out on samples in accordance with PN-EN ISO 6892-1_2010P on a Zwick Roell testing machine. At the same time, three-point bending tests were performed on properly prepared samples to determine the Poisson's ratio. Obtained test results allowed to carry out simulation tests of stress distribution in the sample using the finite element method using MSC Software Patran. The model and simulation were made taking into account the sample geometry, material properties, boundary conditions and load. A comparative analysis of the value of results obtained from experimental tests of sample stretching with numerical calculations was performed.
\end{abstract}

Keywords: static tensile test, MSC Patran, analysis, numerical modeling, FEM.

Cite this Article: Daria Zuk, Grzegorz Hajdukiewicz and Norbert Abramczyk, Simulation Tests of Static Tensile Testing of the AW 5083 Alloy, International Journal of Mechanical Engineering and Technology (IJMET), 12(4), 2021, pp. 36-44. https://iaeme.com/Home/issue/IJMET?Volume=12\&Issue $=4$ 


\section{INTRODUCTION}

Experimental testing of strength properties of materials is one of the commonly used tools in material and mechanical engineering. The results of such research bring a lot of information about the structure of the material or the possibilities of its use [1 - 3].

CAE (Computer Aided Engineering) software, based on the use of finite element methods for numerical simulation, in combination with CAD (Computer Aided Design) programs are excellent support for the work of an engineer, constructor and designer [4, 5]. With the help of this type of software, which includes the MSC Patran program, you can solve solid mechanics issues and model e.g. strength tests such as static tensile testing.

The purpose of this work is to numerically model a static tensile test in software based on the finite element method.

The subject of the test is a sample made of aluminum alloy AW 5083. Standardized samples made of this material were subjected to a static tensile test carried out in accordance with PNEN ISO 6892-1_2010P [6] on a universal Zwick Roell testing machine. Based on the sample geometry and material constants, i.e. Poisson's ratio and Young's modulus, which was determined on the basis of the conducted tests, a numerical model of the sample was created using the MSC Patran program. This program simulated the method of fixing the sample and the applied tensile force, then after the numerical analysis of the model, the values of tensile stress in the measuring part of the sample were obtained. The results of these stresses were compared with the results obtained by the experimental route.

\section{DESCRIPTION OF THE TESTED MATERIAL AND RESEARCH METHODOLOGY}

Aluminum alloys have an attractive combination of mechanical and physical properties, such as relatively high strength and low specific gravity [1].

AW-5083 aluminum alloy has high corrosion resistance in sea water, is a very weldable alloy, has a relatively high fatigue and corrosion and fatigue strength $[1,7,8,9]$.

Mechanical tests were carried out on samples that were made of a $12 \mathrm{~mm}$ thick sheet metal. Samples were cut transversely to the rolling direction. Static tensile tests were carried out in accordance with the applicable standard [6]. The tests were carried out on three samples. The shape and dimensions of the samples are shown in Figure 1.

The chemical composition of the sheet, in accordance with the certificate, is given in Table 1. Independently of the data contained in the certificate, the chemical composition of the tested alloy was determined using the Solaris CCD Plus optical spectrometer, the Italian company G.N.R. Optica. The chemical composition was determined as the arithmetic mean of five measurements.

Table 2 gives the geometrical sizes of the tested samples for static tensile testing. Sampling was carried out on a universal Zwick Roell MPMD P10B testing machine with an Epsilon Model 3542 extensometer (Figure 2). Test results for 3 samples were recorded using Zwick \& Roell-testXpert II version 3.61.

The Poisson's ratio of the tested alloy was determined on the basis of the test, subjecting the samples to three-point bending in accordance with the applicable standard [10]. 
Table 1 Chemical composition of the AW-5083 alloy sheet based on measurements made with the Solaris CCD Plus optical emission spectrometer

\begin{tabular}{|l|l|}
\hline Material name & $\mathrm{AW}-5083$ \\
\hline Chemical composition & $4,27 \% \mathrm{Mg} ; 0,31 \% \mathrm{Mn} ; 0,35 \% \mathrm{Fe} ; 0,28 \% \mathrm{Si} ;$ \\
& $0,04 \% \mathrm{Cu} ; 0,06 \% \mathrm{Cr} ; 0,01 \% \mathrm{Zn} ; 0,02 \% \mathrm{Ti} ;$ \\
& $0,03 \% \mathrm{Ga} ;$ rest- $\mathrm{Al}$ \\
\hline Declaration of conformity & $1141807 / 55125 / 2018$ \\
\hline Norm & EN AW-5083 \\
\hline
\end{tabular}

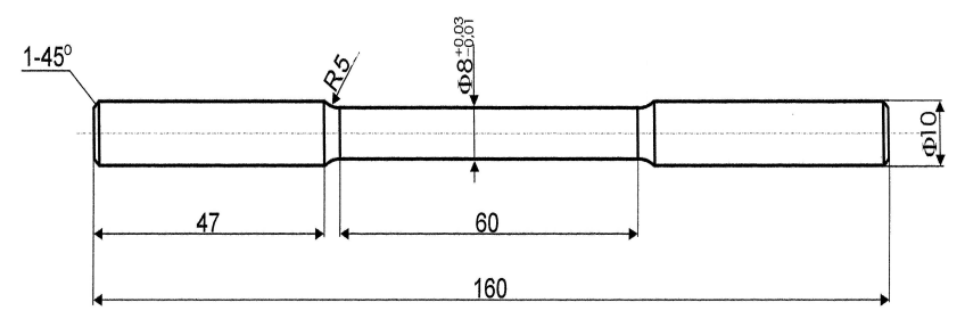

Figure 1 The shape and dimensions of the sample for static tensile testing

Table 2. Geometric dimensions of the samples for static tensile testing

\begin{tabular}{|c|c|c|c|c|}
\hline Sample No. & $\begin{array}{c}\boldsymbol{L}_{\boldsymbol{c}} \\
{[\mathbf{m m}]}\end{array}$ & $\begin{array}{c}\boldsymbol{L}_{\boldsymbol{o}} \\
{[\mathbf{m m}]}\end{array}$ & $\begin{array}{c}\boldsymbol{d}_{\boldsymbol{o}} \\
{[\mathbf{m m}]}\end{array}$ & $\begin{array}{c}\boldsymbol{S}_{\boldsymbol{o}} \\
{\left[\mathbf{m m}^{2}\right]}\end{array}$ \\
\hline 1 & 60.38 & 50 & 7.95 & 49.64 \\
\hline 2 & 60.62 & 50 & 7.80 & 47.78 \\
\hline 3 & 60.52 & 50 & 8.00 & 50.27 \\
\hline
\end{tabular}

For this purpose, $600 \times 30 \times 12 \mathrm{~mm}$ samples were made. On the surface of the sample in the central part two independent systems of 4 electrofusion strain gauges were glued (Fig. 3, Fig. 4, Fig., 5). Strain gauges were used to measure the longitudinal and transverse deformation of the sample during its bending. The values of deformations during bending of the beam were recorded using the ZEPWN recorder type CL 460. The value of the Poisson number $v$ was calculated as $-v=\varepsilon_{m 2 i} / \varepsilon_{m 1 i}[11,12]$ so as the ratio of transverse deformation $\varepsilon_{m 2 i}$ to longitudinal deformtion $\varepsilon_{m l i}$.

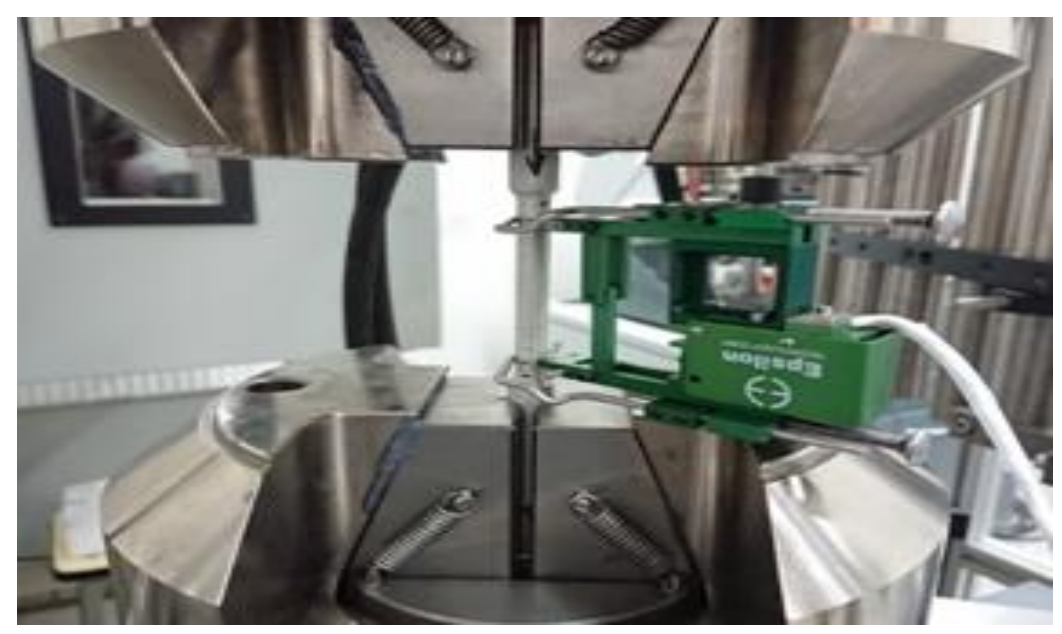

Figure 2. Specimen mounted in Zwick Roell testing machine holders. On sample mounted extensometer Epsilon Model 3542 


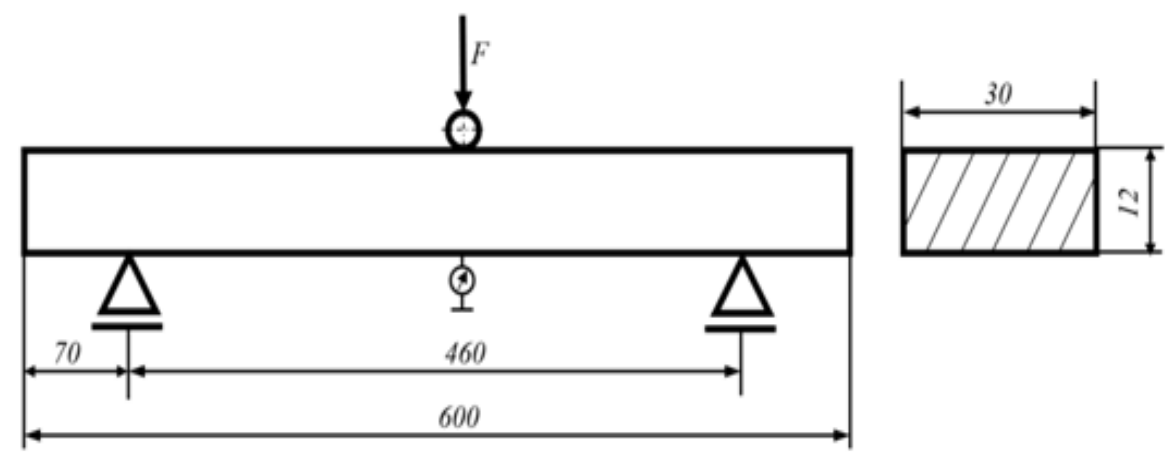

Figure 3 Support diagram for support and load for the sample made of AW-5083 alloy

a)

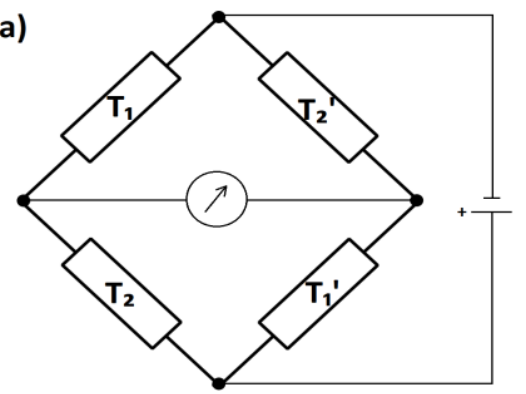

c)

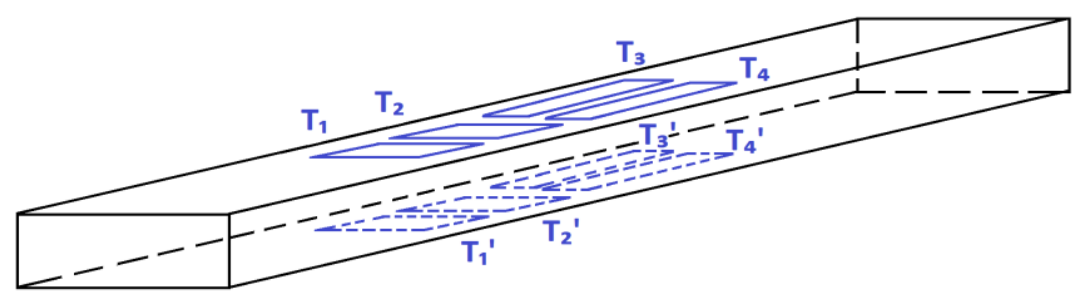

b)

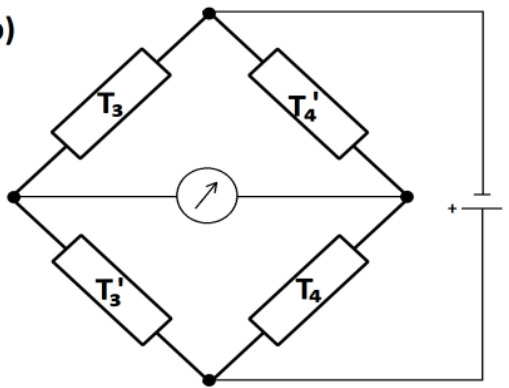

Figure 4. Diagram of measuring systems for determining the Poisson's number $v$ by means of electroresistance strain ganges

a) strain gauge system measuring deformation across the sample,

b) strain gauge system measuring deformation along the sample, on the sample

c) determination of strain gauges stuck on the sample

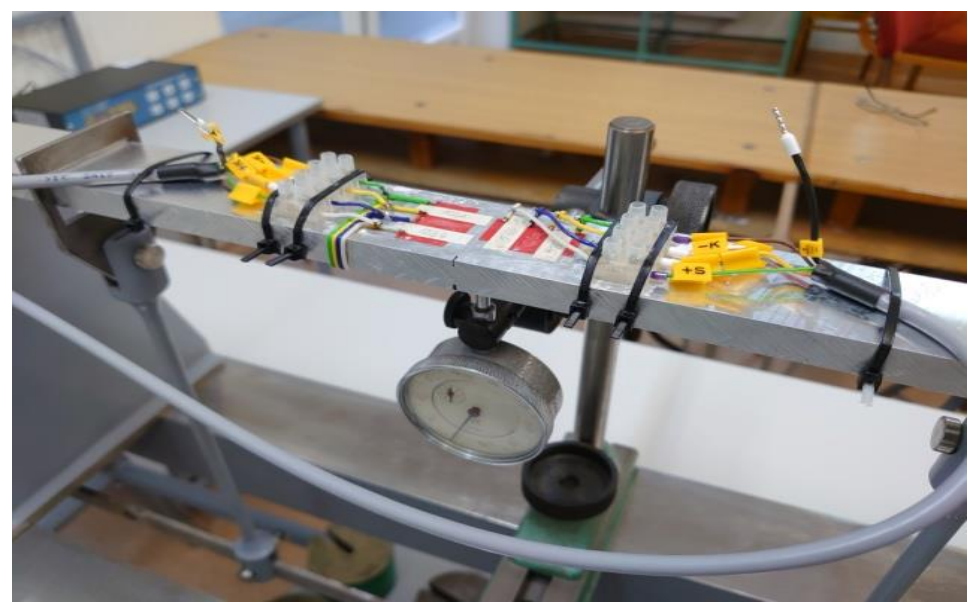

Figure 5. View of the sample bending station with spaced strain gauges. 
Fig. 6 presents graphs of a static tensile test of tested samples from the alloy AW 5083.

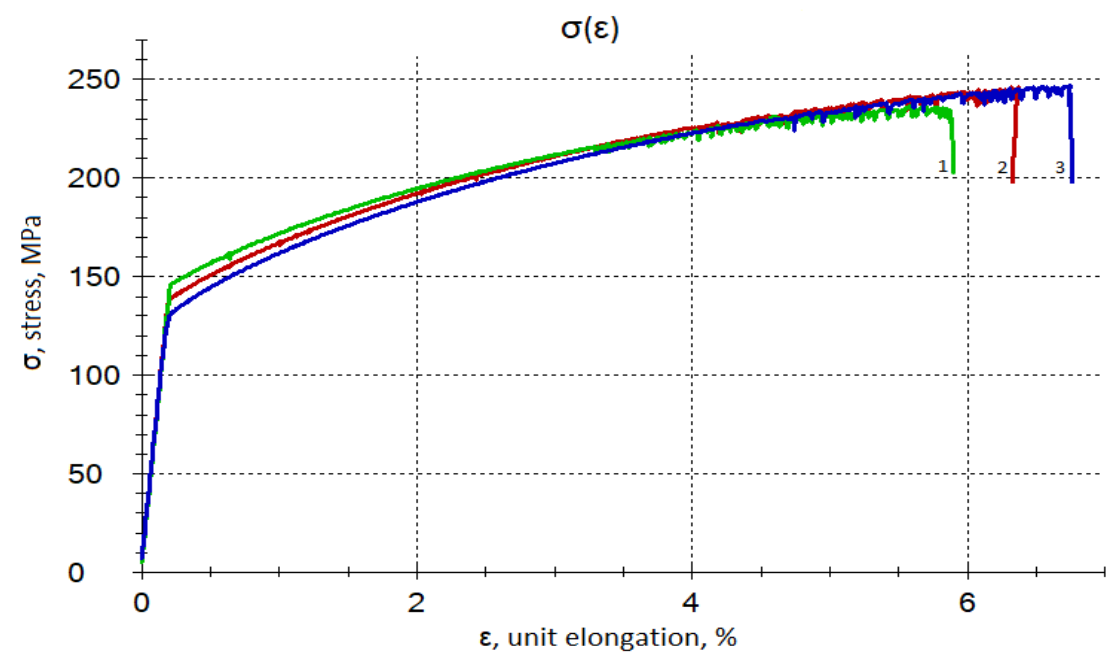

Figure 6. Tensile charts of AW 5083 alloy samples obtained from the Zwick Roell testing machine

It can be observed that the results obtained from the static tensile test are very consistent and repeatable. Table 3 summarizes the results of static tensile test of samples subjected to stretching test.

Table 3. Results of static tensile test of samples made of AW 5083 alloy on a Zwick Roell testing machine

\begin{tabular}{|c|c|c|c|c|c|}
\hline $\begin{array}{c}\text { No of } \\
\text { sample }\end{array}$ & $\begin{array}{c}\boldsymbol{E} \\
{[\mathbf{G P a}]}\end{array}$ & $\begin{array}{c}\boldsymbol{R}_{\boldsymbol{p} \boldsymbol{0 . 2}} \\
{[\mathbf{M P a}]}\end{array}$ & $\begin{array}{c}\boldsymbol{R}_{\boldsymbol{m}} \\
{[\mathbf{M P a}]}\end{array}$ & $\begin{array}{c}\boldsymbol{A}_{\mathbf{5 0}} \\
{[\mathbf{\%}]}\end{array}$ & $\begin{array}{c}\boldsymbol{Z} \\
{[\boldsymbol{\%}]}\end{array}$ \\
\hline 1 & 69 & 154 & 236 & 5.36 & 69,77 \\
\hline 2 & 69 & 147 & 246 & 6.02 & 70,53 \\
\hline 3 & 69 & 140 & 247 & 6.50 & 69,77 \\
\hline average & 69 & 147 & 243 & 5,96 & 70,02 \\
\hline
\end{tabular}

Value of the number $v$ was determined as the arithmetic mean for 7 load values in the range of elasticity of the bending force of the sample. The measurement results are given in Table 4.

Table 4. Determination of Poisson number from measurements from a three-point bending test

\begin{tabular}{|c|c|c|c|c|c|}
\hline $\mathrm{Nr}$ & $\begin{array}{c}F \\
{[\mathbf{N}]}\end{array}$ & $\varepsilon_{m 2 i}[\mathrm{um} / \mathrm{m}]$ & $\varepsilon_{m l i}[\mathrm{um} / \mathrm{m}]$ & $\begin{array}{c}\boldsymbol{v}_{\boldsymbol{i}} \\
{[-]}\end{array}$ & $\begin{array}{c}\boldsymbol{v} \\
{[-]}\end{array}$ \\
\hline 1 & 0 & 0 & 0 & 0 & \multirow{7}{*}{0,31} \\
\hline 2 & 8,26 & 16,6 & $-5,3$ & 0,319 & \\
\hline 3 & 13,28 & 26,8 & $-8,5$ & 0,317 & \\
\hline 4 & 18,29 & 37,2 & $-11,8$ & 0,317 & \\
\hline 5 & 23,32 & 47,7 & $-15,1$ & 0,316 & \\
\hline 6 & 28,36 & 58,2 & $-18,4$ & 0,316 & \\
\hline 7 & 33,39 & 68,8 & $-21,8$ & 0,316 & \\
\hline
\end{tabular}




\section{SIMULATION TESTING OF SAMPLE STRETCHING. PREPARATION OF THE STATIC TENSILE TEST MODEL IN MSC PATRAN. DESCRIPTION OF BOUNDARY CONDITIONS}

To perform the simulation of the static tensile test in the MSC Patran and Nastran software, the sample geometry and strength parameters of the tested material were used.

Figure 7 shows a sample model made in MSC Patran software. The model was assigned material properties of the aluminum alloy AW 5083 determined during static tensile and bending tests. The model was divided into finite elements using the "mesh" function [13, 14]. The model was divided into 1535 Hex elements. The elements were connected with each other using 1819 nodes. After dividing the model into finite elements, the boundary conditions and sample load were applied at the nodes connecting the model's elements.

When modeling the sample fixation in the machine holders, simulation of permanent fixation was used. For this purpose, the model receives 6 degrees of freedom in the nodes located in the middle of the sample part mounted in traverse holders.

In the part of the sample in which the attachment in the traverse handles was modeled, 2 degrees of freedom were received, such as linear displacement along the $\mathrm{y}$ and $\mathrm{z}$ axis. The calculations also took into account the gravitational force required by the solver 129, used to analyze the model $[5,14]$. The tensile force was applied to the same nodes in which the degrees of freedom were taken away to model the attachment in the traverse handles.

The model file with geometry and division into finite elements prepared in the mentioned way was exported for analysis of stresses arising after loading the sample in the MSC-Nastran program.

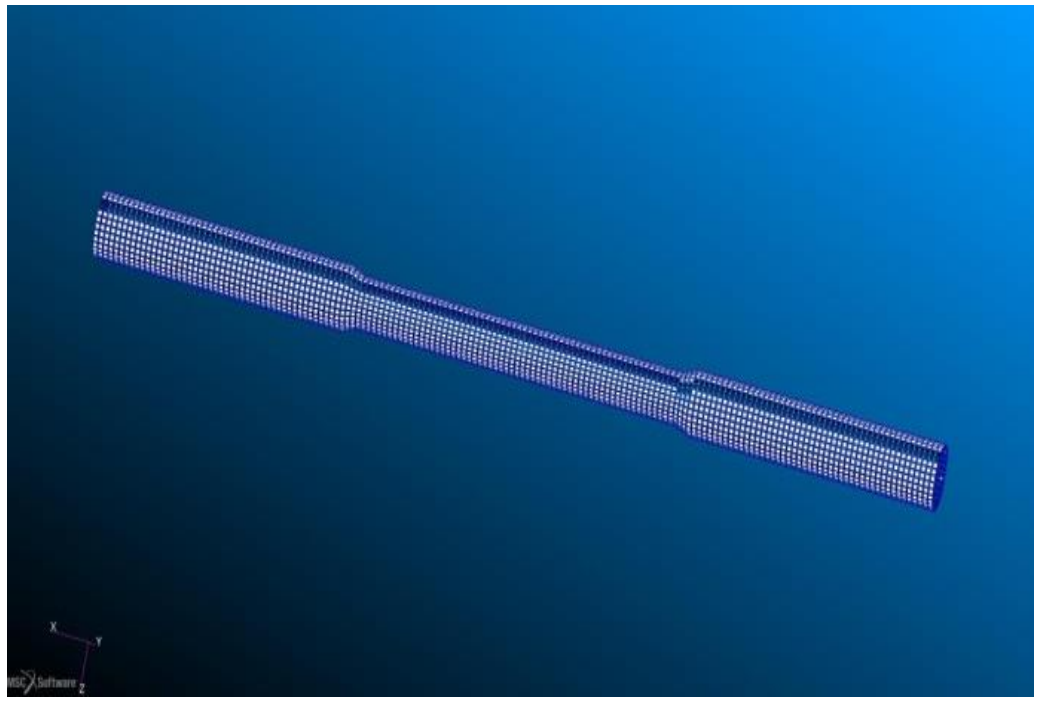

Figure 7. Sample made of alloy AW 5083 model broken down into elements. Results of the analysis in MSC Nastran

For the numerical analysis of the static tensile test model in MSC Nastran, the output file of a computer application combined with a Zwick Roell testing machine was used.

Figure 8 shows the stress distribution of von Misses sample created in the Patran program after loading the sample. In the middle of the sample, the maximum stress values of the sample material corresponding to $221 \mathrm{MPa}$ occurred. For comparison, the stress value obtained from the testing machine for identical load value was $227 \mathrm{MPa}$. The difference in stress values from measurements and calculations was about $2 \%$. 
Comparison of tensile stress values obtained as a result of tensile simulation and analysis in MSC Patran and Nastran for identical load values is shown in Table 5.

Comparison of stress values in the measuring part of the sample is presented by means of the diagram in Figure 9.

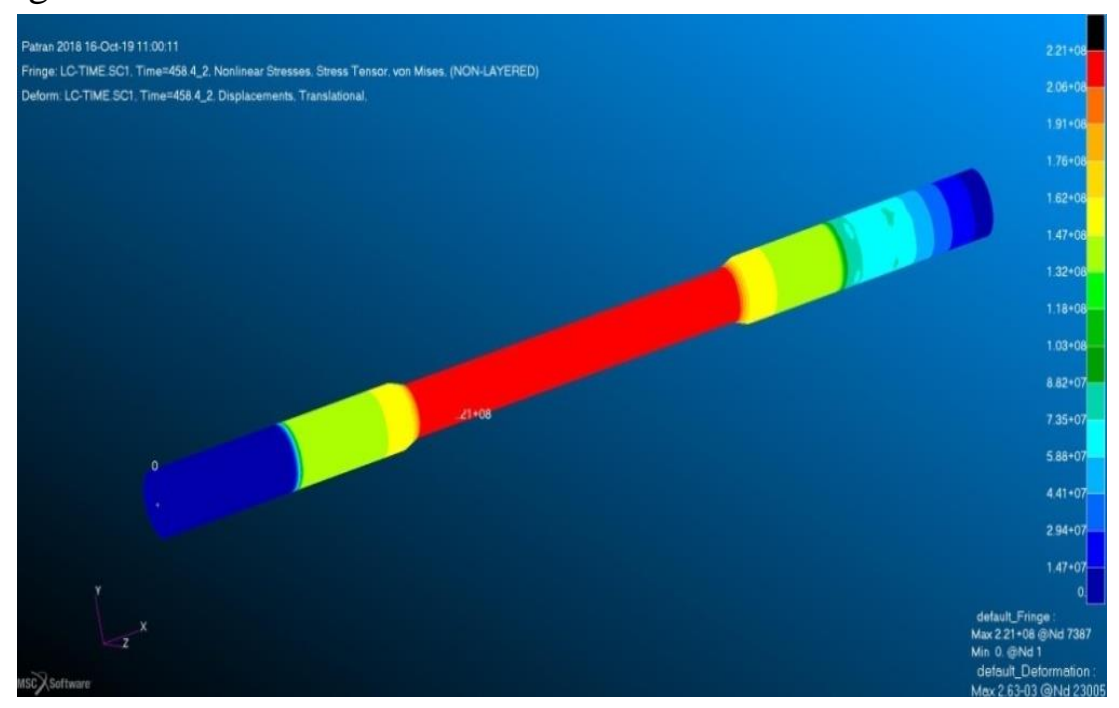

Figure 8. Stress distribution in the sample subjected to tension using the MSC Nastran software

Table 5. Summary of static tensile test results based on tests and calculations

\begin{tabular}{|c|c|c|c|}
\hline $\begin{array}{c}\boldsymbol{\varepsilon}[\%] \\
\text { deformation }\end{array}$ & $\begin{array}{c}\text { 6 [MPa] } \\
\text { Tensile stress } \\
\text { obtained from } \\
\text { Zwick Roell } \\
\text { machine }\end{array}$ & $\begin{array}{c}\text { 6 [MPa] Tensile } \\
\text { stress obtained } \\
\text { from } \\
\text { calculations in } \\
\text { MSC Patran }\end{array}$ & $\begin{array}{c}\text { Percentage difference } \\
\text { (in relation to } \\
\text { experimental results) }\end{array}$ \\
\hline 0,39 & 140,00 & 133,00 & $5 \%$ \\
\hline 0,84 & 157,00 & 168,00 & $-7 \%$ \\
\hline 1,31 & 171,00 & 173,00 & $-1 \%$ \\
\hline 1,74 & 182,00 & 176,00 & $3 \%$ \\
\hline 2,19 & 192,00 & 203,00 & $-5 \%$ \\
\hline 2,64 & 201,00 & 203,00 & $-1 \%$ \\
\hline 3,09 & 209,00 & 202,00 & $3 \%$ \\
\hline 3,53 & 216,00 & 227,00 & $-5 \%$ \\
\hline 3,94 & 222,00 & 224,00 & $-1 \%$ \\
\hline 4,34 & 227,00 & 221,00 & $2 \%$ \\
\hline
\end{tabular}

Figure 9 presents the characteristics of the static tensile test obtained on the basis of tests and calculations. 


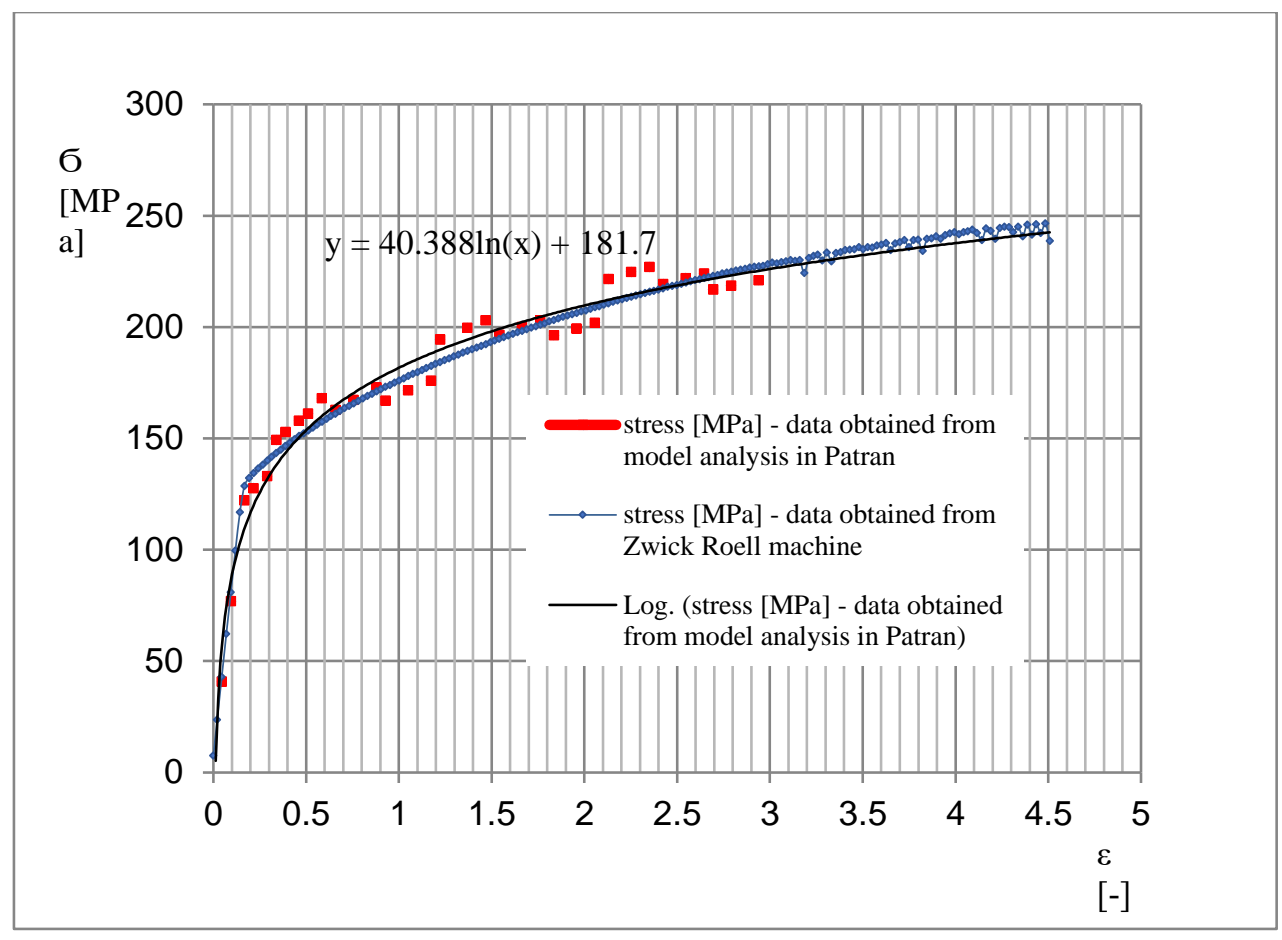

Figure 9. Comparison of tensile test characteristics obtained from tests on the Zwick Roelll machine and simulation tests

\section{ANALYSIS OF RESEARCH RESULTS AND FINAL CONCLUSIONS}

The study presents tests of static tensile testing of samples from aluminum alloy AW 5083 and based on them simulation tests. The MSC Patran and Nastran package was used in the simulation tests. Studies have shown that the use of this program leads to very similar results. The difference in values obtained on the basis of tests and calculations is on the order of several percent. The data should be prepared carefully for calculations, because the final result depends on them.

The method of creating a geometric model in FEM-based software has a large impact on the convergence of real and numerical simulation results $[4,5,13]$. The type of elements used to divide the model into finite elements also affects the results [15 - 17]. It is related to the accuracy and choice of the function calculated in the middle of the selected finite element.

The best solution in this case was to use Hex elements when dividing the sample model into finite elements. Hex elements do not cause the need to improve connections between nodes in mesh elements. After applying transition rounding, Hex type mesh could not be applied to the entire model - it was necessary to use the Tet element mesh. As a result, many unrelated nodes appeared and the analysis in MSC Nastran failed.

It should be noted that the creative and responsible use of FEM requires an understanding of the basics of the method and its conditions [4]. In MSC Patran, like other programs based on the use of the FEM method, the model can be built in several ways. Discretization involving the selection of the type and number of finite elements determines the correctness of the solution obtained in the context of the approximate nature of FEM. The results obtained as a result of model analysis are approximate, which is a feature closely related to numerical methods, which is why they differ from the analytical solution.

Comparison of the obtained data also allows to draw the conclusion that it is impossible to achieve full convergence of the obtained results with the results obtained by the experimental route due to the mathematical model used for iteration in the program [15 - 17]. 
MSC Patran software is characterized by very high sophistication of the implemented finite element method. MSC Patran is one of the best programs based on the finite element method [5]. Virtually every engineering task is possible to analyze using the above software. The problem with using these types of programs is their complexity. The user must have theoretical knowledge and experience in using this software to achieve useful results of simulations.

\section{REFERENCES}

[1] Kyzioł L., Czapczyk K., Influence of heat treatment on stress - corrosion resistance of EN AWAIZn5Mg1,5CuZr alloy, Solid State Phenomena, Mechatronic System and Materials, Vol. 199, 2013, pp. 424-429.

[2] Kyzioł, L. Reinforcing wood by surface modification. Composite Structures. Volume 158, 15 December 2016, Tom 1, Pages 64-71.

[3] Kyzioł, L. Dynamic properties of 40HM steels at high strain rates. Transations of Famena XLIII. pp.55 - 68, 2019, Tom 1, doi.org/10.21278/TOF.43405.

[4] Mika, P.Support for materials for classes FEM analysis of elstic problems at ABAQUS problems. Koszalin : Politechnika Koszalińska, 2011.

[5] Zienkiewicz, O. i Zhu, J.A simple error estimator and adaptive procedure for practical enginneering analysis. 2 pp 337-358, Warszawa : Numerical Methods in engineering, 1987, Tom Vol.24.

[6] Normalizacji, Polski Komitet.PN-EN ISO 6892-1:2010 Metale Próba rozciagania. Część 1. Metoda badania w temperaturze pokojowej. Warszawa : PKN, 2010.

[7] Hajdukiewicz, G. Impact of the type of quench aging after hyperquenching on the mechanical strength properties of AW-7020 alloy. Journal of KONES. Vol. 25, 2018, Tom 2, 1.

[8] Kyzioł, L. Application of the Kolmogorov-Sinai Entropy in Determining the Yield Point, as Exemplified by the EN AW-7020 Alloy. Journal of KONBiN. Vol. 49, 2019, Tomy Issue 3, pp. 241-269, DOI.org/10.2478/jok-2019-005.

[9] Kyzioł, L. i Komarov, A. Influence odf Micro-Arc Oxidation coatings on Stress Corossion of ALMg6 Alloy Materials. Materials. 13, 2020, Tom 2, PP 1-11, DOI.ORG/10.3390/MAL3020456.

[10] Normalizacyjny, Polski Komitet. Metale, Próba zginania. PN-EN ISO 7438:2016-03. Warszawa : Poslki Komitet Normalizacyjny, 2016.

[11] Obst, M.Energetyczny model materiału o nieliniowych właściwościach. Politechnika Poznańska. Poznań : Politechnika Poznańska, 2007.

[12] Kyzioł, L. The influence of temperature and strain rate on the strengthening of metallic materials. Journal of Kones. Vol. 23, 2016, Tom 2, pp. 199-206.

[13] J.Chruścielewski, S.Burzyński,K.Daszkiewicz,B.Sobczyk,W.Witkowski.Wprowadzenie do modelowania w programie Abaqus. Gdańsk: Wydawnictwo Politechniki Gdańskiej, 2014.

[14] Zienkiewicz, O.Metoda elementów skończonych. Warszawa : Politechnika Warszawska, 1979.

[15] https://simulatemore.mscsoftware.com/patran-tip-student-tutorials. [Online] online access, 08.2019 .

[16] Kruszewski J., Gawroński W., Wittbrodt E.Metoda sztywnych elementów skończonych. Warszawa : Politechnika Warszawska, 1975.

[17] Konderla, P.Metoda elementów skończonych $w$ mechanice konstrukcji. Warszawa : Politechnika Warszawska, 2010. 